\title{
Os híbridos cantam: a constituição do pensamento moderno, a poética Marubo e os estudos de poesia
}

Resumo: $\mathrm{O}$ artigo discute possibilidades abertas aos estudos de poesia a partir de poéticas ameríndias, voltando-se, em específico, às contribuições do antropólogo e tradutor Pedro Cesarino (2013), em "Quando a Terra deixou de falar”, antologia de cantos míticos da etnia amazônica Marubo. Tendo este objetivo em vista, é recuperada a discussão de Bruno Latour (2013) sobre a Constituição do pensamento moderno e suas garantias, para, em seguida, promover uma reflexão sobre como a poesia moderna, e precisamente a sua crítica, não escapa a este paradigma - pelo contrário, nele se inscreve. Para tanto, é trazido à tona o embate entre Berardinelli (2007) e Friedrich (1978) em torno da imanência e transcendência da poesia lírica, e da postura acusatória que dá dinâmica ao pensamento moderno. Feito isto, o texto retoma a poética Marubo e o ato tradutório de Cesarino $(2008 ; 2013)$, como maneira de evidenciar uma poética vinda de outra cosmovisão, em tudo distinta a nossa, mas, sobretudo, para discutir como o olhar para esta poética pode nos fazer repensar paradigmas que formulam a epistemologia moderna e, por extensão, os pilares hegemônicos da crítica acerca da poesia.

Palavras-chave: poética Marubo, constituição moderna, híbridos, estudos de poesia

Abstract: The article discusses possibilities open to the study of poetry based on Amerindian poetics, focusing specifically on the contributions of anthropologist and translator Pedro Cesarino (2013), in "When the Earth stopped talking", anthology of mythical songs from the ethnic group amazonian Marubo. With this objective in mind, the discussion of Bruno Latour (2013) on the Constitution of modern thought and its guarantees is recovered, to then promote a reflection on how modern poetry, and precisely its criticism, does not escape this. paradigm - on the contrary, it is inscribed in it. For this, the clash between Berardinelli (2007) and Friedrich (1978) around the immanence and transcendence of lyric poetry, and the accusatory posture that gives dynamics to modern thought, is brought up. That done, the text resumes the poetry Marubo and the translational act of Cesarino (2008; 2013), as a way to highlight a poetics coming from another worldview, in everything different from ours, but, above all, to discuss how to look at this poetics it can make us rethink paradigms that formulate modern epistemology and, by extension, the hegemonic pillars of criticism about poetry.

Keywords: Marubo poetic, modern constitution, hybrids, poetry studies 
A poesia brasileira contemporânea passa por um momento efervescente, em especial pelos esforços, coletivos e individuais, de colocar em cena corpos e poéticas historicamente marginalizados. Prova disso é o espaço que editoras independentes dedicadas ao gênero têm alcançado, descortinando como pensar na produção de determinado momento histórico, mais que uma rede coesa, é um amalgamado de fios que se interconectam, ainda que frouxos entre si. Dentre estas vozes, que se erguem, chama a atenção o espaço conquistado por poéticas ameríndias, fazendo com que se torne indispensável colocá-las na equação, ao falarmos sobre poesia contemporânea brasileira. Exemplo disso, por um lado, é a consolidação de poetas como Eliane Potiguara, que, com seu Metade cara, metade máscara, tem sido lida e estudada nas universidades do país, tensionando o próprio conceito de poesia. Por outro, iniciativas editoriais, como a coleção Pensamento indígena, da editora Hedra, demonstram como fazer com que o amplo público conheça estas produções não se restringe a iniciativas individuais, ou dos autores. Por óbvio, não desejo afirmar, com isto, que as poéticas ameríndias sejam uma novidade ou que estes exemplos pontuais sejam representativos de toda esta rede, em si muito mais ampla. Pelo contrário, a inovação está em como os leitores e o circuito não indígena começam, finalmente, a olhar para estas produções a partir de outra mirada, que não a do exótico ou a do primitivo.

A isto, somam-se os esforços tradutórios dos etnógrafos que, em suas pesquisas, dedicam-se às culturas originárias. Como lembra Cesarino (2013), sobre o trabalho antropológico, é incontornável a contribuição de Claude Lévi-Strauss, através das Mitológicas, onde se encontra um compilado de narrativas dos povos indígenas sul- americanos. Após, já nas décadas de 1970 e 1980, "uma nova geração de etnólogos vai aliar a pesquisa de campo sistemática com a compreensão mais sofisticada das línguas e de suas respectivas configurações poéticas e rituais" (Cesarino 2013: 11). Com este passo, a disciplina começa a enxergar com mais cuidado os aspectos estéticos das culturas estudadas, fazendo com que as traduções se sofistiquem e ganhem centralidade no campo. Esta preocupação, por sua vez, fez com que a Antropologia se abrisse a um diálogo interdisciplinar, "ao combinar a etnomusicologia, a etnolinguística e a etnografia para revelar uma série de características das artes verbais das terras baixas que permaneciam obscuras ou pouco sistematizadas" (idem: 12). É certo, porém, que muitas destas traduções são lidas majoritariamente por outros pesquisadores, em especial aqueles que se ocupam de temáticas correlatas. Logo, tais produções, ainda hoje, encontram-se distantes da circulação editorial e, por conseguinte, do grande público.

Este não é o caso das traduções do antropólogo brasileiro Pedro Cesarino (2011;2013). O cientista dedicou-se a estudar a poética dos cantos Marubo, povo amazônico radicado na Terra Indígena do Vale do Javiri, e, em 2013, publicou pela Editora 34 a obra Quando a Terra deixou de falar, que, em suas palavras, "é uma antologia de traduções de narrativas míticas dos Marubo do Alto Rio Ituí, extremo oeste do Amazonas” (Cesarino 2013: 7). Aqui, destaca-se o fato de a publicação ser o resultado do acúmulo das investigações de 
Cesarino, como se pode ver na tese de doutorado do autor, "Oniska - a poética da morte e do mundo entre os Marubo da Amazônia ocidental” (Cesarino 2008), mas, sobretudo, parte de um diálogo intenso - uma relação - com os cantadores Marubo - Armando Mariano Marubo, Antonio Brasil Marubo, Paulino Joaquim Marubo, Lauro Brasil Marubo e Robson Dionísio Doles Marubo. Estes, como o tradutor afirma, foram fundamentais para que fossem possíveis as traduções, não apenas pelos entraves da transposição de uma língua a outra, mas por todos os câmbios de cosmovisão e de concepções sobre as artes verbais que esta poética expõe, quando em contraste com a cosmologia ocidental - e com sua concepção particular de poesia.

Assim, se dizia, na abertura deste texto, que o reconhecimento das poéticas ameríndias trouxe uma lufada ao cenário atual da poesia brasileira, é preciso constatar, em um primeiro momento, que a publicação de Cesarino (2013), ao romper com os limites contextuais da circulação de textos acadêmicos, insere-se nesta dinâmica. Mas, além disso, o trabalho de aliar o exercício tradutório à reflexão sobre tradução e poesia contribui, na mesma medida, para as elaborações sobre as artes verbais e os estudos de tradução expressão da multidisciplinariedade que o próprio antropólogo afirma na apresentação de Quando a Terra deixou de falar. Sobre isto, vale trazer as palavras de Faleiros (2019: 135) acerca de Cesarino: "um dos autores que mais tem contribuído para a incorporação das artes verbais ameríndias ao repertório da literatura brasileira, explorando de modo profícuo os limites entre poética e antropologia, pensando-as por meio da tradução e do xamanismo". Faleiros continua discorrendo sobre como o trabalho do antropólogo revela-se importante para os estudos da tradução, tendo em vista a correlação estabelecida entre o ato tradutório e a prática xamânica - tema já desenvolvido anteriormente em outras produções antropológicas, como ele mesmo aponta (Faleiros 2019).

Este tema é sobremaneira interessante, dado que a cosmologia Marubo oferece uma visão outra de conceitos tão caros à cultura ocidental - tais como natureza, cultura, sujeito e corpo. Logo, através deste contato entre cosmologias distintas, os Estudos da tradução têm enveredado nesta reflexão, que aproxima a figura do tradutor e a do xamã, com suas descontinuidades. Me parece um grande chacoalho na área de tradução, no qual todos se afetam. Explico melhor. Partindo do acordo para a abertura multidisciplinar que as poéticas ameríndias suscitam nas ciências humanas, na filosofia e nas artes, entendo que as reflexões circunscritas no campo dos Estudos da tradução não se limitam a ele. Mais, ao lermos os cantos Marubo, fica patente que, para esta cultura, o conhecimento e a vida, em si, não se desenrolam num som unívoco, mas numa polifonia rítmica, em vozes que se intercomunicam em vários níveis - timbres que permitem, ou não, ouvir. Por isso, acredito que se, tal qual a relação entre tradução e xamanismo é uma questão procedimental, este entrelaçamento disciplinar tem algo a ver com esta outra maneira de conhecer, onde a comunicação é profícua e confluente.

Isto não significa, entretanto, que os Marubo (Cesarino 2008; 2013) não saibam bem sua linhagem parental ou não deem importância para quem sejam os enunciadores dos 
cantos. Pelo contrário, partícipes de um mundo onde tudo comunica, é muito importante saber enxergar a si e ao outro, retraçar o corpo para incrustar sua humanidade. Trago esta consideração para chegar ao que desejo, aqui, neste espaço, desenvolver, ainda que de maneira embrionária. Considerando o percurso tracejado, interessa-me pensar como o trabalho poético de Cesarino, via tradução, em Quando a Terra deixou de falar (Cesarino 2013), contribui para a Crítica literária, ao pôr em causa o conceito de poesia, flanqueado ao deparar-se com outra cosmovisão. Esta questão é o que justifica a relação com outras disciplinas, por um lado, e a busca por uma contribuição específica para a área dos Estudos literários - que engloba os Estudos da tradução, ainda que com corpo próprio. Ora, tal debate não seria possível em um único artigo; todavia, acredito que um primeiro passo possa ser dado. Este movimento, entendo, deve ser em direção a como a Crítica literária tem, ao longo da modernidade, lidado com a noção de poesia e como isso se articula com a nossa epistemologia, a nossa maneira de conhecer e produzir conhecimento. A partir disto, o diálogo com as traduções de Cesarino (2013). Sem ser uma fórmula analítica, este é o meu desejo de encontro. Uma relação entre epistemologias que a crítica se engaje em traduzir.

\section{Constituição do pensamento moderno e poesia lírica}

Neste momento, a fim de construir meus apontamentos, deixarei em suspenso as traduções de Cesarino (2013), às quais voltarei na seção seguinte. Por agora, farei um recuo necessário para olhar, de forma mais detida, para a noção de poesia na modernidade. Tal concepção, no Ocidente, em muitos momentos se mescla à concepção de lírica, o que faz com que estas duas categorias, neste contexto, caminhem de mãos dadas. Este aspecto, por si só, já demonstra como a nossa visão das artes verbais, ao contrário do que nossa tradição tentou transparecer, é particular, e, mais do que a noção de poesia, revela acerca do próprio pensamento moderno. Portanto, ao invés de trazer uma compilação de conceitos ou visões provenientes dos estudos e da crítica à poesia na modernidade, entendo ser mais proveitoso refletir sobre como este pensamento se constitui, partindo da premissa que estas áreas não se apartam do problema geral da epistemologia ocidental - pelo contrário, fazem parte e são afetadas por este.

Sobre este ponto, escolho, para iniciar a discussão, trazer as elaborações de Bruno Latour (2013) sobre a Constituição moderna, isto é, sobre o paradigma que "define os humanos e não-humanos, suas propriedades e suas relações, suas competências e seus agrupamentos" (Latour 2013: 21). Tendo este objetivo em vista, o antropólogo recorre a duas figuras de extrema relevância para tal Constituição: o cientista natural Boyle, e Hobbes, responsável por estruturar em grande medida as nossas bases políticas e jurídicas. A opção pelos autores é justificada por estes, aparentemente, não convergirem, sendo, em muitos momentos, vistos como diametralmente opostos. Isto porque, com Boyle, desenvolveu-se o que Latour (idem: 23) chama de "metáfora parajurídica": seus experimentos em ambientes controlados são validados pela opinião, e não pela doxa. 
Esta apreciação, entretanto, não é feita por qualquer sujeito ou grupo interessado; pelo contrário, é proferida por aqueles "cavalheiros" capazes de produzirem uma observação criteriosa do fenômeno analisado, sendo, por conseguinte, mais que uma simples opinião. Com isso, continua Latour (2013), Boyle funda o entendimento de que, em um ambiente artificial e controlado, forças e leis da natureza, até então incompreensíveis, tornam-se passíveis de serem estudadas pelos homens - e, aqui, a escolha por homens, e não por sujeitos ou pessoas, não é mera desatenção.

A formulação de Boyle, ademais, gera uma grande segurança à comunidade científica. Uma vez que, através do isolamento do fenômeno, é possível estudá-lo sem interferências, os resultados aos quais se chega serão intransponíveis, dado que "estes fatos jamais serão mudados, aconteça o que acontecer em termos de teoria, de metafísica, de religião, de política, ou de lógica”. Hobbes, por sua feita, se insurge contra esta concepção, tendo em vista seu objetivo de "negar todos os apelos a entidades ditas superiores à autoridade civil” (idem: 24). E isto porque, para o filósofo, estabelece-se uma simetria entre conhecimento e poder, que não deve ser desestabilizada por qualquer força, ou ente, que coloque em causa a figura do soberano - como a Natureza ou Deus. Logo, a "metáfora parajurídica" de Boyle, ao produzir sentenças através das observações de um grupo seleto, seria contrária à materialização do poder do soberano. Ou, como explica Latour (2013), por tais formulações não serem fruto de um cálculo exato - inquestionável e consensual -, elas escapam da esfera de poder e controle do Estado, sendo "experiências observadas pelos sentidos enganosos, experiências que permanecem sem explicação e pouco conclusivas" (idem: 25).

Outro aspecto que chama a atenção, ainda sobre o método de Boyle, fundante das ciências naturais, é o papel que os não-humanos passaram a desempenhar, imbuídos de uma autoridade impossível aos humanos. Por serem "corpos inertes", os não-humanos, objetos e elementos da natureza, seriam incapazes de proferir um juízo de valor ou uma ideia pré-concebida. Logo, aquilo que estes apontam e descrevem ganha um status outro, pois é a eles que os cientistas vão recorrer, com o objetivo de sanar suas dúvidas diante do desconhecido. A estes não-humanos, expostos ao ambiente controlado, Latour (2013) denomina "híbridos", a partir dos quais os sujeitos da comunidade autorizada formulam suas leis e alimentam os debates. Novamente, esta maneira de relacionar-se com os híbridos, para Hobbes, é dissonante com o Leviatã e o pacto social, uma vez que atribui o conhecimento - e por extensão o poder - a outro agente, que não o próprio tecido social. Com isso, pode-se pensar que os autores escolhidos por Latour em nada convergem. Entretanto, é justamente esta ideia que o antropólogo desconstrói, ao afirmar que:

Em outras palavras, eles inventaram nosso mundo moderno, um mundo no qual a representação das coisas através do laboratório encontra-se para sempre dissociada da representação dos cidadãos através do contrato social. [...] Era preciso que, a partir de então, todos "vissem imagens duplicadas" e não fosse estabelecida uma relação direta entre a representação dos 
não-humanos e a dos humanos, entre o artifício dos fatos e a artificialidade do corpo bonito. A palavra "representação" é a mesma, mas a controvérsia entre Hobbes e Boyle tornou impossível a similitude dos sentidos da palavra (Latour 2013: 33, grifos do autor).

Estas “imagens duplicadas” geram uma separação das maneiras de representação, produzindo o efeito de parecem irreconciliáveis. Latour (idem: 37), entretanto, segue, argumentando que tais "garantias" - a de que, por um lado, a natureza nos transcende, enquanto a sociedade é uma construção social, e, por outro, a de que nós construímos em um ambiente artificial e controlado a natureza, sendo ela imanente, enquanto a sociedade nos transcende, como indivíduos que somos - do pensamento moderno formam a mesma Constituição, sempre reiterando os movimentos de imanência e transcendência, sem, com isto, unir os polos que se apresentam separados - ciência e sociedade. Para concluir esta equação, o antropólogo discorre sobre como insere-se uma quarta garantia: a supressão de Deus, que deve ser mantido afastado tanto da ciência quanto das leis que regem o tecido social. Logo, a divindade não desaparece, mas é colocada "em parênteses", imbuída de uma transcendência que se afasta em muito do humano, ainda que possa, a qualquer momento, ser reivindicada pelo sujeito moderno, no caso de choque entre as distintas leis.

Por fim, interessa-me destacar, neste momento, ainda de acordo com Latour (2013), como esta Constituição do pensamento moderno produz, incessantemente, seus híbridos, ao construir mediações com forças e entes alheios aos seres humanos - seja a natureza ou o corpo social, o Leviatã. Mas, justamente por esta Constituição se perfazer através da garantia de que ciência e sociedade têm leis divergentes, há, na mesma medida, um movimento de purificação. Como consequência deste, soma-se outra postura fundante do sujeito moderno: a postura crítica. A depender do ponto de referência, se abre uma possibilidade crítica distinta, nublando a constituição dos híbridos, e pondo em marcha um movimento que se reifica, numa crítica constante: quando se parte da transcendência da natureza, critica-se a impossibilidade da ação humana diante da natureza; quando se parte da imanência da natureza, se critica pelo fato de nós, seres humanos, termos possibilidades infinitas. Na mesma medida, quando se parte da imanência da sociedade, advoga-se pela liberdade do conjunto social; e, quando se tem como ponto de partida a transcendência da sociedade, o crítico argumentará que nada podemos diante das leis sociais. Desta forma, a postura crítica, como um procedimento purificatório, faz com que sujeito moderno se sinta triunfante, ao apontar os problemas do ponto de partida do outro, ainda que os dois escamoteiem seus híbridos produzidos.

Bruno Latour (2013) continua sua explanação, alertando para como as ciências humanas não escapam à Constituição; pelo contrário, nela se inscrevem. É precisamente a este ponto que gostaria de chegar, pois, como disse no início da seção, meu interesse neste momento é olhar para a concepção de poesia - e por extensão de lírica - erigida na modernidade. Acho insuficiente, porém, apenas estender os apontamentos do autor para a crítica de poesia, sem com isso acompanhar nenhuma análise de como esta se con- 
formou. Por isso, escolhi, a exemplo do que foi feito com Boyle e Hobbes, transpor esta reflexão para o embate de dois autores - e especificamente dois textos - seminais para o campo: Hugo Friedrich, com sua "Estrutura da lírica moderna" (1978), lançada nos anos 1950, e o mais recente "Da poesia à prosa", de Alfonso Berardinelli (2007). A escolha não é em vão, tendo em vista que me dedicarei à crítica de Berardinelli a Friedrich, num esforço de demonstrar como os estudos da poesia se inscrevem na Constituição do pensamento moderno, através de movimentos de mediação e purificação, entre a imanência e a transcendência. Para tanto, começo pelo caminho reverso - pela crítica.

Berardinelli (2007) abre o capítulo "As muitas vozes da poesia moderna" citando diretamente o livro de Friedrich (1978), e explicitando aos seus leitores o teor da crítica que seria, ali, desenvolvida: apesar de, nos anos 1950, o modernismo e a poesia moderna já terem passado por uma consolidação histórica, o autor insiste em olhar para o fenômeno apenas de um ponto de vista. Precisamente, o faz ao eleger aspectos específicos da poesia de T. S. Eliot que corroboram a sua hipótese, aproximando este poeta de outros, com o mesmo objetivo - dentre os quais se destacam Mallarmé e Paul Valéry, com grande centralidade no escrito de Friedrich (1978). Dito isto, a crítica do autor de "Da poesia à prosa" questiona o caráter transcendental atribuído à poesia moderna pelo seu antecessor, que a coloca como uma poesia "despersonalizada e alheia à história, [...] [que] deve ser lida e analisada como um organismo cultural e estilístico auto-suficiente" (Berardinelli 2007: 21). A insistência, a qual me referi, então, aponta para uma "crença" nas formulações de poetas da virada do século XIX para o XX, como Valéry e Mallarmé, na "arte pela arte", ou, em outras palavras, na autonomia da linguagem poética, em relação ao tecido social. Contra esta ideia, em um primeiro momento, Berardinelli traz outros poetas que vão na contramão de tal formulação poética e, em especial, volta no próprio Eliot, demonstrando como Friedrich, em sua leitura, elege aspectos específicos da poética deste, em detrimento de outros.

Vejamos juntos, então, o que está colocado em "Estrutura da lírica moderna":

A poesia quer ser, ao contrário, uma criação auto-suficiente, pluriforme na significação, consistindo em um entrelaçamento de tensões de forças absolutas, as quais agem sugestivamente em estratos pré-racionais, mas também deslocam em vibrações as zonas de mistério dos conceitos. [...] Ela [a fantasia] é a força que guia o gênio. O que se concede a este, se concede também a ela: ser um movimento autônomo de forças espirituais, cuja qualidade se mede segundo a dimensão das imagens produzidas, segundo a eficácia das ideias, segundo uma dinâmica pura não mais ligada ao conteúdo [...]. (Friedrich 1978: 16; 26)

Assim, para o teórico, a lírica moderna teria se consolidado como uma expressão disruptiva, em relação ao mundo social, em tudo vinculado às preocupações econômicas e científicas. Com isto, o poeta lírico romperia com a tradição, se voltando para si 
e sua própria condição, expressiva e sentimental. Tal ruptura, por sua vez, seria o que levaria a poesia a esta "autossuficiência", um procedimento que se inicia e se encerra na linguagem, distinguindo-se não apenas do corpo social, como também de outros gêneros literários. Ainda, ao pensar no lugar da fantasia, Friedrich, voltando a Diderot, fala como a figura do gênio - tão presente neste movimento de dissonância - retoma a concepção "pré-racional", que atribui a genialidade ao caráter visionário desta. Porém, se antes, imersos numa forma de "selvageria", este caráter ligava-se a um sistema de crenças em entidades outras, não-humanas, agora, na modernidade, este estaria estreitamente vinculado à produção poética - às imagens e às ideias produzidas. Logo, sem uma moral que balize a expressão de tal genialidade, o poeta se permitiria ao desvio, ao erro, tendo como único compromisso seu trabalho com a linguagem.

Berardinelli (2007: 22) contesta tais formulações, acusando Friedrich de um erro metodológico: "não é fácil dizer quanto o método deve ao objeto e quanto o objeto é uma projeção do método". Isto é, por seu opositor teórico dedicar-se a poéticas que exaltam a abstração, sua crítica e formulação sobre a poesia moderna é, na mesma medida, abstrata - como se fosse, ele mesmo, seduzido pelo argumento de seu objeto. Berardinelli, por seu lado, buscará outros exemplos para justificar sua tese: a relevância e a influência do mundo social na poesia lírica, inclusive naquela que se arroga de transcendê-la. E, para tanto, além dos poetas elegidos, o autor recorre às ideias de Adorno, para justificar como os procedimentos criativos das vanguardas, mesmo em exemplos-limite, como a poesia surrealista de Breton, antes de serem uma fuga da realidade, seriam uma retomada desta - dado que entraria em cena aspectos do cotidiano e do que, em outros momentos da história ocidental, estiverem restritos ao prosaico.

Mais, Berardinelli (2007) chama a atenção para como, no pensamento de Adorno, o elemento antirrealista da lírica moderna, tão sublinhado por Friedrich, é interpretado com valor oposto. Assim, para o filósofo da Escola de Frankfurt, a postura de recusa, perante a vida social e suas limitações, demonstra como a poesia moderna se coloca contrária à reificação da vida social, à sobreposição da mercadoria ao ser humano. Logo, "Adorno restitui à questão da obscuridade o seu caráter de risco radical e objetivo, não passível de ser resolvido pela boa vontade elucidativa de uma exegese estilística sistemática” (idem: 34). Ou seja, a poesia moderna não seria apartada do corpo social, nem mesmo o gênio com sua fantasia visionária. Pelo contrário, ela seria inerente à sociedade, pois responderia à dinâmica estabelecida, sendo esta calcada na relação capital trabalho e na produção capitalista - segundo a interpretação materialista-histórica do período.

Poderia continuar destrinchando a polêmica entre Friedrich e Berardinelli, porém, acredito que esta breve apresentação já seja o suficiente para voltar à noção de Constituição desenvolvida por Latour (2013). Berardinelli (2007) ataca a "exegese estilística sistemática" de Friedrich, posto que esta afirmaria - retomando os termos de Latour - a transcendência do sujeito lírico, da poesia moderna. Contra esta ideia, toma de empréstimo a análise de Adorno para dizer sobre os limites de tal transcendência, dada a imanência do 
corpo social. No sentido oposto, posso imaginar que Friedrich contra-argumentaria, atestando a liberdade da poesia e questionando a imanência ilimitada atribuída à sociedade. Ora, o primeiro golpe, desferido por Berardinelli, ataca uma maneira de construir o conhecimento, uma exegese, que se ocupa de um "espaço controlado", produto da criação humana - os poemas modernos. O segundo, que imaginariamente atribuo a Friedrich, por conseguinte, opõe-se à ideia de que, de uma ou outra forma, a poesia esteja circunscrita ao pacto social, sem poder, portanto, ser produto de uma "opinião parajurídica" (Latour 2013), considerando os consensos construídos em torno da poesia a partir da observação de uma comunidade autorizada - composta por poetas, teóricos e críticos de poesia.

De uma ou outra maneira, acredito que o que se revela é o movimento crítico apontado por Latour (2013). Além disso, se, no caso de Boyle, os não-humanos são tidos como entes de autoridade, desprovidos de preconceitos ou outros prejuízos humanos, aqui, entendo que podemos considerar os próprios poemas como estes híbridos - que, a todo momento, passam por processos de "mediação" e "purificação", a fim de corroborar não apenas um posicionamento crítico, como, em última instância, a Constituição do pensamento moderno (Latour 2013). Por fim, o debate em torno do caráter visionário da poesia moderna parece trazer o que Latour (2013) denominou de quarta garantia: um Deus em parênteses, um ente que não é contabilizado na operação crítica, mas que permanece em ausência, ao qual se pode recorrer de forma emergencial.

Se assim o é, parece coerente afirmar que as formulações modernas acerca da noção de poesia não se apartam da Constituição do pensamento moderno (Latour 2013). Tal qual as ciências humanas, elas fazem parte da Constituição, pela relação com os híbridos e pela produção de um efeito de purificação, que faz com que os polos - transcendência da lírica e imanência das regras sociais - se apresentem de maneira separada e irreconciliável. Chegar a este apontamento, por sua vez, é o que me permite retomar a pergunta norteadora deste texto: como refletir sobre a poética Marubo e a tradução de Cesarino (2013), tendo como questão os tensionamentos que estas produzem nos estudos de poesia. Dessa maneira, acredito que tenha sido necessário explicitar, como tentei, como os estudos de poesia na cosmovisão moderna se inserem na Constituição (Latour 2013), fazendo com que, apesar de poderem apresentar críticas e posicionamentos aparentemente em tudo distintos, participam do mesmo jogo acusatório, que revitaliza conceitos subjacentes à modernidade, para além do de poesia e de lírica - tais quais o conceito de ser humano, não-humano, natureza e cultura.

\section{Os cantos Marubo e os estudos de poesia}

Os cantos reunidos na antologia "Quando a Terra deixou de falar" (Cesarino 2013), como dito, são reflexo do trabalho etnográfico de Pedro Cesarino e do diálogo com os cantadores Marubo do Alto Rio Ituí, na região amazônica. A investigação antropológica tem como desdobramento a busca por compreender a cosmovisão Marubo e como esta produz significações e ideias outras para noções, tais como a de pessoa, natureza e cul- 
tura. Na obra, estas elaborações não se colocam da mesma maneira como nos trabalhos científicos de Cesarino (cf. 2008), mas, ainda assim, na "Apresentação", o autor dedica-se a introduzir a cultura Marubo em linhas gerais, apontando as descontinuidades entre a cosmologia deste povo e a moderna. Sobre isto, de partida, Cesarino (2013) aponta como, ao reunir os "mitos" Marubo, não se fecha na conceituação "greco-europeia" de mito, que retoma a filosofia ocidental. Nesta, continuando com o antropólogo, as narrativas mitológicas assumem uma acepção simbólica, apartada do real - o que não ocorre nos cantos mitológicos Marubo. Nestes, pelo contrário, “'mito’ designa apenas uma inteligência narrativa e sua disposição verbal de ações específicas ocorridas nos tempos primeiros, e nada além disso" (Cesarino 2013: 20).

Logo, a conceitualização de mito da epistemologia moderna não será suficiente para olhar para a mitologia Marubo, uma vez que o sentido destas narrativas segue "suas próprias condições de verdade", revelando não apenas a criação do mundo e dos sistemas de parentesco, segundo a perspectiva Marubo, como explicitando uma maneira de construir e transmitir o conhecimento dentro dessa sociedade. Além do conceito de mito, outra descontinuidade entre cosmovisões, de pronto, demonstra-se patente: a noção de pessoa. Segundo os cantadores Marubo - xamãs e, portanto, profundos conhecedores e transmissores do conhecimento - ensinaram a Cesarino, o corpo, para eles, é compreendido como uma "carcaça" ("shaká"), "na qual habitam agentes diversos, os vaká, aqui traduzidos por 'duplos', na medida em que, para si mesmos, eles também possuem (ou são) corpos (e não exatamente 'almas' etéreas, fugazes, imateriais)”. Estes “duplos”, então, "se articulam em uma tríade de irmãos", sendo "os responsáveis pelas competências intelectuais e poéticas do sujeito identificado ao corpo-carcaça”, chamados pelos cantadores, e pelo antropólogo, como "viventes" (idem: 21).

Tais duplos, por conseguinte, são capazes de se deslocar, ao saírem do corpo-carcaça, e, ao entrarem em contato com espíritos outros, os yovevo, "mais sábios e loquazes que os humanos" (idem: 22), aprenderem estas narrativas e os cantos, os saiti. Tal deslocamento, continua Cesarino, não é, entretanto, fruto de um processo coletivo e indistinto, como muitas vezes foram colocadas as artes verbais ameríndias, ao serem julgadas como "primitivas" (ou pré-modernas). Pelo contrário, este percurso é feito pelos pajés/xamãs, que trilham um caminho de conhecimento, ao passo que o transmitem através do entoar de seus cantos ritualísticos. Assim, qualquer tentativa de generalizar as artes verbais Marubo incorre no erro de não reconhecer as especificidades desta. Dentre elas, ademais, destaco: a relação de autoria, que perpassa as noções de corpo-vivente, de duplos e de contato com outros seres; as diferentes formas narrativas - a "fala contada" e os cantos ("saiti") em si -; e a questão da estrutura narrativa - e reiteração de elementos constituintes desta - e das versões e características particulares de cada performance xamânica. Sobre esta última, Cesarino (2013) afirma que, em decorrência dela, sua antologia não apresenta aos leitores uma reunião definitiva de todos os cantos Marubo. Pelo contrário, esta tarefa seria impossível, não apenas pelos cantos se estenderem em narrativas diversas, e/ou combi- 
nadas de diferentes maneiras, mas também pelas versões múltiplas cantadas, e contadas, por cantadores diferentes.

Este é o caso, por exemplo, do primeiro canto traduzido por Cesarino, precisamente - Quando a Terra deixou de falar, que narra como os antigos seres do Povo Sol decidiram silenciar a Terra, "e os demais elementos-locutores" - como as montanhas, o céu e os rios -, sendo esta decisão fruto do comportamento sexual dos antigos Marubo, ao contarem sobre suas relações sexuais e, assim, cansarem a vida dos outros elementos-locutores. Desta maneira, após este momento inaugural, apenas os xamãs romeya continuaram sendo capazes de ouvir o que diziam estes interlocutores, sendo, por extensão, os responsáveis pela transmissão destes ensinamentos aos outros membros da sociedade Marubo. Ou, nas palavras do xamã cantador Armando Marubo, ao ser perguntado por Cesarino se o rio falava nesta época de surgimento: "As pessoas mais humanas não escutam, mas quem tem ouvido-espírito, como eu, escuta as falas do pessoal do rio. Escuta mesmo" (idem: 53). Tal narrativa fundacional, contudo, apesar de reunir traços em comum, possui mais de uma versão, como o antropólogo expressa ao contrastar a versão de Armando e a cantada por Paulino Joaquim Marubo - esta publicada na íntegra, na antologia aqui referida.

Estes elementos, obviamente, são insuficientes para construir um panorama inicial da poética e da cosmovisão Marubo. Entretanto, acredito que, com eles, já seja capaz de avançar na minha argumentação. Ao traduzir os cantos da mitologia Marubo, e deparando-se com tantas descontinuidades entre a cosmovisão deste povo e a nossa, o antropólogo relata como a transposição linguística implicou uma série de escolhas, como a versificação em verso livre e não com um metro fixo, como há nos cantos na língua original. Ainda, Faleiros fala como, em sua tradução, Cesarino, "ao entrecruzar, em seu livro, recriação poética e investigação etnográfica", produz uma "outra forma de reescrita” (Faleiros 2019: 142). Por isso, o trabalho do antropólogo traz uma discussão sobre o processo tradutório enquanto prática criativa, onde se colocam em movimento deslocamentos, "como um complexo em que mundos variam" (ibidem). Sem despojar-se de sua própria cosmovisão, Cesarino, através de sua tradução, desloca-se, ao relacionar-se com os cantadores Marubo e seus cantos, entrando em contato com um mundo onde as garantias modernas não são as mediadoras. O tradutor, com isso, aproxima-se do xamã, com sua capacidade de transitar e aprender com espíritos e outros entes, de outros povos. Logo, o que se vê, ao trazer a discussão para os estudos da tradução, é um debate em torno da relação entre epistemologias distintas, e como a Marubo pode afetar a nossa, via este campo do conhecimento.

Acredito que esta discussão, por sua vez, afeta na mesma medida os estudos da poesia, como, aliás, o próprio etnógrafo afirma: "A ideia, mais uma vez, é fazer com que tais pressupostos [envolvidos nos estudos de literatura e filosofia] possam ser torcidos ou problematizados à luz das idiossincrasias alheias, a fim de encaminhar uma maneira possível de compreender (e recriar) as condições de uma poética xamânica" (Cesarino 2008: 141). Isto é, se sua prática tradutória pressupõe uma série de escolhas, estas, por ex- 
tensão, atrelam-se a outras decisões, que giram em torno de pressupostos de áreas como os estudos da literatura - e eu diria, especificamente, da poesia - e da filosofia. Dentre estas escolhas, em sua tese, o autor destaca a polifonia presente nos cantos, o processo de colagem e citação, e o trabalho com as figuras de linguagem, a exemplo das metáforas. As categorias consolidadas por estes campos na modernidade, contudo, não poderiam apenas ser transpostas para a poética Marubo, sem com isso apagar as especificidades desta arte verbal e sua cosmologia.

No sentido contrário, Cesarino $(2008 ; 2013)$ aposta em uma torção, na qual, por um lado, não seja sublimado o ponto de referência do próprio antropólogo, e, por outro, este seja afetado pelo contato - pela relação - com esta outra cosmovisão. Mais, acredito que se a tradução se depara com uma "disparidade radical" de formas e imagens, produzir uma leitura crítica sobre esta poética (traduzida e recriada) deve ser um investimento radical nesta torção, problematizando como as concepções sobre a palavra poética foram cristalizadas no pensamento moderno. Ou seja, os debates explicitados por Cesarino (2008; 2013) e suas escolhas iniciam este procedimento - e a eles, como críticos, devemos recorrer. Para além, outros desdobramentos são possíveis, não apenas tendo em vista as leituras sobre os cantos Marubo, mas também sobre as considerações teórico-críticas de Cesarino e, sobretudo, acerca das formulações consolidadas na modernidade sobre as artes verbais e a poesia.

\section{Terra outrora falava / Mas de falar deixou}

Por fim, entendo que este movimento proposto por Cesarino (2008; 2013) não se limita a um contraste com uma reunião de conceitos, e textos, formulados pelo campo dos estudos de poesia e literatura. Antes, me parece que o que está em causa é como produzir um pensamento crítico sobre esta poética, tendo em vista o jogo acusatório que perfaz a Constituição do pensamento moderno (Latour 2013), demonstrado na primeira seção deste texto através do embate protagonizado por Berardinelli (2007) e Friedrich (1978). Não é, portanto, algo que escape ao problema geral de produção de conhecimento na cosmovisão moderna, tendo em vista que esta dinâmica é o que constitui nossa compreensão do que é humano e o que é não-humano - e como com estes nos relacionamos. Mas, a isto, soma-se o choque entre constituições de pensamento radicalmente distintas - a nossa, moderna, e a Marubo. Logo, além de não ser possível transpormos conceitos de uma à outra, sem considerar as descontinuidades entre estas, acredito fazer falta entendermos como o olhar para esta poética ameríndia pode transformar o olhar sobre nossa própria Constituição.

Sobre isto, Latour (2013) chama a atenção para como é infrutífero rejeitarmos (como se fosse possível) a compreensão desta Constituição, instaurando um marco de superação da modernidade - um "pós" que repete a postura moderna, ao rejeitar o passado. Em outro sentido, o autor sugere uma solução alternativa, "a partir do momento em que seguimos ao mesmo tempo a Constituição e aquilo que ela proíbe ou permite, a partir do 
momento em que estudamos de perto o trabalho de produção de híbridos e o trabalho de eliminação destes híbridos" (Latour 2013: 51). Com isso, não se trata de superar ou rejeitar a modernidade, mas compreender como a modernidade, em seu desejo de purificação, excluiu de seu discurso os híbridos e as redes que se formam no espaço do meio, entre uma ou outra garantia. E, ainda, compreender como, se o sujeito moderno é aquele que constrói sua imagem de purificador e que se coloca em uma postura acusatória, a modernidade, justamente pelos seus híbridos, nunca se realizou.

Portanto, voltando ao campo da poesia, em consonância com a proposta de Latour (2013), penso não se tratar de optar, e defender, entre a transcendência da palavra poética ou a imanência do tecido social. Mas sim de olhar de perto como a poesia pode ser percebida enquanto este híbrido que se constitui na rede que se forma a partir do entrecruzamento destas relações de imanência e transcendência. Nesta procura por purificação, em uma cultura que se pretende moderna, contudo, nossos híbridos têm a voz cerceada ou tutelada, no sentido de servir a um ou a outro argumento acusatório. Me parece, então, que, tal qual no canto "Quando a Terra deixou de falar" (Cesarino 2013), somos incapazes de ouvir o que falam estes entes, estes corpos híbridos que são os poemas - algo que, na mesma medida, parece apontar para nossa fundação enquanto sociedade.

E, se assim o é, talvez um bom caminho para nos aproximarmos dos nossos próprios híbridos seja fazer como os Marubo: aprender com o procedimento xamânico que, via deslocamentos e contato com outros entes, é capaz de, através dos cantos, produzir conhecimento e transmiti-lo. Ou, em outras palavras, mais que fazer nossos híbridos cantarem, aprender a ouvi-los, deixá-los cantar. Nesta perspectiva, as traduções e as formulações de Cesarino (2013), ao trazerem a poética Marubo, mas também um processo de transcriação poética, abrem uma possibilidade ao campo dos estudos da poesia não só por enxergar um cenário contemporâneo da poesia brasileira onde seja reconhecido o espaço das poéticas ameríndias. Sobremaneira, o valor do estudo do antropólogo, para o campo, talvez resida em, através das descontinuidades entre as cosmovisões e as formulações em torno da palavra poética, aprendermos a ouvir o que calamos, o que os nossos próprios híbridos contam e, quem sabe assim, chegar a uma crítica que se permita cantar. 
* Fernanda Vivacqua Boarin é mestra em Letras - Estudos literários, pela Universidade Federal de Juiz de Fora, instituição onde também se licenciou em Língua Portuguesa e suas respectivas literaturas; atualmente, é doutoranda na linha de pesquisa Teoria, crítica e comparatismo, do Programa de Pós-graduação em Letras, da Universidade Federal do Rio Grande do Sul. Tem interesse nos estudos de poesia e, precisamente, em processos de criação poética que envolvam, de uma ou outra maneira, o uso de substâncias psicoativas.

\section{BIBLIOGRAFIA}

Berardinelli, Alfonso (2007), “Da poesia à prosa”, in Da poesia à prosa, São Paulo, Cosacnaify, 17-41.

Cesarino, Pedro de Niemeyer (2008), Oniska - A poética da morte e do mundo entre os Marubo da Amazônia ocidental, Tese (Doutorado em Antropologia social) -, Programa de Pós-graduação em Antropologia Social, Museu Nacional, Universidade Federal do Rio de Janeiro, Rio de Janeiro, 2008. $469 \mathrm{f}$.

Cesarino, Pedro de Niemeyer (Org. e tradução) (2013), Quando a Terra deixou de falar: cantos da mitologia Marubo, São Paulo, Editora 34.

Faleiros, Álvaro (2019), “A poética de traduzir de Pedro Cesarino: na partilha das águas”, in Traduções canibais - uma poética xamânica do traduzir, Florianópolis, Cultura e Barbárie, 135-156.

Friedrich, Hugo (1978), "Perspectiva da lírica contemporânea: dissonâncias e anormalidade", in Estrutura da lírica moderna: da metade do século XIX a meados do século XX, São Paulo, Duas cidades, 1978, 15-34.

Latour, Bruno (2013), "Constituição", in Jamais fomos modernos - Ensaios de antropologia simétrica, São Paulo, Editora 34, 19-52. 